\title{
SCIDiC
}

International Journal of Chronic Diseases \& Therapy (IJCDT)

ISSN: 2572-7613

\section{Occupational Contact Dermatitis in the Food Industry}

Research Article

Lahya Afshari Saleh ${ }^{1}$, Nasrin anvari ${ }^{2}$, Bita Kiafar $^{3}$, Farzaneh Rahimpour ${ }^{*}$

${ }^{1}$ Assistant professor, Department of Occupational Medicine, Division of Sleep Medicine, Psychiatry and Behavioral Sciences Research Center,Mashhad University of Medical Sciences, Mashhad, Iran.

${ }^{2}$ Occupational Medicine specialist, Faculty of Medicine, Mashhad University of Medical Sciences, Mashhad, Iran

${ }^{3}$ Associate professor, Cutaneous leishmaniasis research center, Mashhad University of Medical Sciences, Mashhad, Iran.

${ }^{4}$ Assistant professor, Department of Occupational Medicine, Faculty of Medicine, Mashhad University of Medical Sciences, Mashhad, Iran.

\section{Abstract}

Background: Contact dermatitis accounts for $90 \%$ of all occupational skin diseases which is considered a costly occupational disease. The aim of the present study was to investigate contact dermatitis and relevant occupational factors among food industry workers.

Study Design: The present cross-sectional study was carried out among food supply, production, distribution and preservation centers of Mashhad, Iran from 2017 to 2018.

Methods: Workers in food industry who were referred to periodic training centers for employees entered the study with at least one year of work experience. The two-part questionnaire including demographic and occupational information and the occupational skin questionnaire (Nordic Occupational Skin Questionnaire (NOSQ-2002/SHORT), which is validated in Persian, was filled by the participants. Individuals with dermatitis were examined and the results were recorded.

Results: A total of 384 food industry workers entered the study including $316(82.3 \%)$ men and $68(17.7 \%)$ women. $32(8.4 \%)$ subjects were suffering from eczema, among which $25(78.1 \%)$ had hand eczema, $6(18.8 \%)$ had both wrist and hand eczema and $1(3.1 \%)$ had eczema confined to the wrist. The statistical analysis revealed that gender and previous familial and personal history of atopy were significantly correlated with hand and wrist eczema (P-value $\leq 0.05$ was significant).

Conclusion: Prevalence of dermatitis varies in food industry workers regarding the job status. In this study, occupational dermatitis proved to be more prevalent among men and individuals with a personal or family history of atopy, thus these people should be under strict supervision of health practitioners working in the food industry. Further studies are recommended among the employees of certain subunits of the food industry.

Keywords: Occupational Dermatitis; Contact Dermatitis; Nordic Occupational Skin Questionnaire; Food Industry Workers.

\section{Introduction}

Occupational dermatosis (OD) or occupational skin disease (OSD) is described as any pathological condition of the skin, which is caused or worsened by an occupational exposure [1]. Skin diseases account for more than $30 \%$ of all occupational diseases, affecting approximately 1 per 1000 workers annually and are responsible for decreased productivity and lost workdays in different industries [1]. Environmental chemicals are among the main causes of OSDs and there are about 2000 substances known as contact allergens [1]. Approximately $90 \%$ of all OSDs are reported as contact dermatitis $[9,10]$. The food and catering industries account for more than $10 \%$ of all occupational dermatitis, which is considered as a major occupational health threat. The most important workers at risk include chefs, cooks, kitchen and catering assistants and counter hands. Waiters, cleaners, bakers, confectioners, greengrocers and meat, poultry and fish handlers are among other workers at risk in this area [5]. In most of the food and catering jobs, prolonged contact with water, soap and disinfectants required for hygiene issues causes more than 55\% of dermatitis cases. More than $40 \%$ of occupational dermatitis in industry is due to contact with foods, including sugar, flour, fruits, vegetables, seasonings, seafood, meat and poultry [5]. Occupational dermatitis may be seen mainly as irritant contact dermatitis and allergic contact dermatitis [6]. Various host factors may have a role in developing occupational dermatitis, such as history

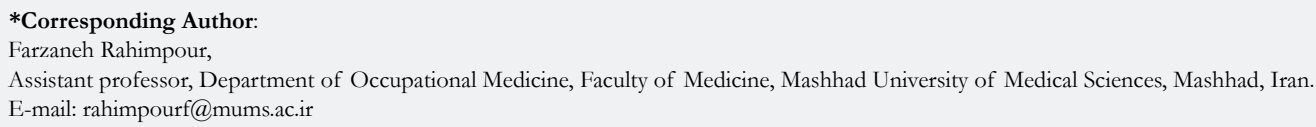

Citation: Lahya Afshari Saleh, Nasrin Anvari, Bita Kiafar, Farzaneh Rahimpour. Occupational Contact Dermatitis in the Food Industry. Int J Cbronic Dis Ther. 2021;7(2):118-122. doi: http://dx.doi.org/10.19070/2572-7613-2100024

Copyright: Farzaneh Rahimpour ${ }^{\circ} 2021$. This is an open-access article distributed under the terms of the Creative Commons Attribution License, which permits unrestricted use, distribution and reproduction in any medium, provided the original author and source are credited. 
of atopy, pigmented skins, old and wrinkled skins and immune deficient workers. White people, compared with blacks are more prone to dermatitis $[7,8]$. The primary aim of this research was to investigate contact dermatitis and its related occupational factors among food handlers and sellers.

\section{Materials and Methods}

This cross-sectional study was carried out under supervision of Mashhad University of Medical Sciences form 2017 to 2018. Regular training courses are conducted in Iran for food preparers, distributers and sellers including greengrocers, butchers, bakers, confectioners and restaurant, catering and fast-food staff. Subjects referred to these training centers were studied using random sampling method within one year period. Those who had foodrelated occupations for at least one year in the city of Mashhad were included in this study and exclusion criteria were as follows: dissatisfaction for entering the study, immunocompromised cases, using immunosuppressive drugs and previous history of a skin disease before employment. A two-part questionnaire, including a demographic checklist designed by the author and the validated Nordic Occupational Skin Questionnaire (NOSQ-2002/SHORT) was used. Cases with dermatitis were examined by occupational medicine specialists and referred to our dermatologist colleague for a precise diagnosis. Data were collected and entered into the SPSS V.20 Software. The relationship between the frequency of dermatitis and job-related factors were evaluated with the T-test, chi-squared test and Fisher's exact test. The level of significance was 0.05 for all tests.

\section{Findings}

\section{Demographic indices}

A total of 384 food handlers in the city of Mashhad were studied. $316(82.3 \%)$ cases were male and $68(17.7 \%)$ cases were female. Among the participants, $288(75 \%)$ cases were married and 96 $(25 \%)$ were single. According to education levels, 6 were illiterate $(1.6 \%), 340$ had a high school diploma or less $(88.5 \%)$ and $38 \mathrm{had}$ higher education $(9.9 \%)$. Among the participants of this study 32 $(8.3 \%)$ cases had a pet. $32(8.4 \%)$ subjects were suffering from eczema, $25(78.1 \%)$ of those had hand eczema, $6(18.8 \%)$ had both wrist and hand eczema and $1(3.1 \%)$ had eczema confined to the wrist. Subjects with hand and/or wrist eczema were asked regarding probable factors of dermatitis in or out of the work place. Among them $4(12.5 \%)$ cases believed that the probable factor was outside the workplace while 17 (58.6\%) cases blamed workplace for developing the disease. The number of subjects suffered from itchy, dry and scaly skin were $2(0.5 \%), 54(14.1 \%)$ and $2(0.5 \%)$, respectively. $18(4.7 \%)$ cases reported more than one skin symptom and $308(80.2 \%)$ cases showed no skin symp- toms. $42(10.9 \%)$ cases stated that seasonal changes altered the skin symptoms and $342(89.1 \%)$ believed that seasonal changes had no effect on their skin. Table 1 shows the frequency of hand eczema according to the time of occurrence.

The relationship between the quantitative and qualitative demographic and occupational variables was appropriate according to the statistical tests. Table 2 illustrates the qualitative demographic and occupational variables in two groups of patients with hand eczema and healthy individuals.

Table 3 shows the frequency of occupations in both study groups. Chi-squared test was used to compare the frequency of jobs in both study groups, through which no significant difference was detected between the two groups, in terms of current jobs $(\mathrm{P}=0.49)$.

Moreover, table 4 depicts the quantitative demographic and job variables in two groups of patients with hand eczema and healthy individuals. The relationship between annual eczema recurrence while working and occupation types was studied based on an appropriate statistical test and no significant relationship was found $(\mathrm{P}=0.67)$ (Table 5).

The relationship between eczema improvement during weekends within a year and occupation types was studies and no significant relationship was detected $(\mathrm{P}=0.86)$ (Table 6$)$.

\section{Discussion and Conclusion}

Of the 345 employees working as food preparers, distributers and sellers $32(8.4 \%)$ subjects had eczema. The annual prevalence of dermatitis was $7.5 \%$ in this study. Recent studies on occupational health indicate that food-related occupations are among the major factors contributing to contact dermatitis $[2,5]$. Smith et al. reported the annual prevalence of skin disorders in food industry among kitchen workers was 1414 people per million. The study was performed on 193,132 personnel using a questionnaire. Skin disorders were higher among cases who had wet-work exposure [21]. In another study on 1052 food industry workers in Finland in 1985 , Peltonen et al. showed that $17 \%$ of their study population were suffering from skin diseases. The frequency of occupational eczema was $8.5 \%$ which was twice higher among fish, meat and vegetable handlers and also confectioners. Hand eczema existed in $15 \%$ of the food handlers and $6 \%$ of the office employees [19]. Other studies reported a higher prevalence. According to a study by Sylvia Teo et al. (2003), the prevalence of occupational dermatitis among 457 restaurant, catering and fast-food staff in Singapore was $10 \%$ within a year [22]. The incidence of occupational dermatitis was reported 34\% among 90 food services workers in Poland [18] and in another research the annual inci-

Table 1. Timing of Skin Symptoms in Patients with Dermatitis.

\begin{tabular}{|c|c|c|}
\hline Last skin eczema symptoms seen & Number of patients & Percentage of patients \\
\hline Patients at present & 19 & 5 \\
\hline Within the last 3 months & 3 & 0.8 \\
\hline Within the last 3-12 months ago & 6 & 1.6 \\
\hline More than 12 months ago & 4 & 1 \\
\hline total & 32 & 8.4 \\
\hline
\end{tabular}


Table 2. Evaluating the Qualitative Demographic and Occupational Variables in Two Groups of Patients with Hand Eczema and Healthy Individuals.

\begin{tabular}{|c|c|c|c|c|c|c|}
\hline \multirow{2}{*}{ Variable } & \multirow{2}{*}{$\frac{\text { group }}{\text { subgroup }}$} & \multicolumn{2}{|c|}{ With hand eczema } & \multicolumn{2}{|c|}{ Without hand eczema } & \multirow{2}{*}{$\begin{array}{c}\text { Test statistic } \\
\text { (P-value) }\end{array}$} \\
\hline & & No. & Percentage & No. & Percentage & \\
\hline \multirow{2}{*}{ Sex } & male & 21 & 6.6 & 295 & 93.4 & \multirow{2}{*}{0.01} \\
\hline & female & 11 & 16.2 & 57 & 83.8 & \\
\hline \multirow{3}{*}{ Education } & Illiterate & 0 & 0 & 6 & 1.7 & \multirow{3}{*}{0.41} \\
\hline & High school diploma and lower & 27 & 84.4 & 313 & 88.9 & \\
\hline & Higher than high school diploma & 5 & 15.6 & 33 & 9.4 & \\
\hline \multirow{2}{*}{ Keeping pets } & Own a pet & 30 & $93 / 83$ & 322 & $91 / 5$ & \multirow{2}{*}{0.56} \\
\hline & Do not own a pet & 2 & $6 / 3$ & 30 & $8 / 5$ & \\
\hline \multirow{3}{*}{ Previous job } & No previous job & 23 & $71 / 9$ & 231 & $65 / 6$ & \multirow{3}{*}{0.63} \\
\hline & Related job in food industry & 3 & $4 / 9$ & 28 & 8 & \\
\hline & Work experience in other fields & 6 & $18 / 8$ & 93 & $26 / 4$ & \\
\hline \multirow{2}{*}{ Second job } & With no second job & 32 & 100 & 345 & 98 & \multirow{2}{*}{0.42} \\
\hline & With a second job & 0 & 0 & 7 & 2 & \\
\hline \multirow{2}{*}{$\begin{array}{l}\text { Use of cosmetics and sanitary } \\
\text { materials and skin creams }\end{array}$} & Yes & 24 & 75 & 297 & $4 / 84$ & \multirow{2}{*}{0.17} \\
\hline & No & 8 & 25 & 55 & $6 / 15$ & \\
\hline \multirow{2}{*}{ Use of gloves } & No & 7 & $21 / 9$ & 54 & $15 / 33$ & \multirow{2}{*}{0.33} \\
\hline & Yes & 25 & $78 / 1$ & 295 & $84 / 7$ & \\
\hline \multirow{4}{*}{ The material of gloves used } & Cotton & 0 & 0 & 18 & 6 & \multirow{4}{*}{0.34} \\
\hline & Latex & 14 & 56 & 120 & $3 / 40$ & \\
\hline & Nylon & 3 & 12 & 46 & $4 / 15$ & \\
\hline & Plastic & 8 & $38 / 3$ & 114 & 32 & \\
\hline & Low & 6 & $18 / 8$ & 71 & $20 / 2$ & \\
\hline Hand hygiene procedure & Average & 12 & $37 / 5$ & 173 & $49 / 1$ & 0.29 \\
\hline & High & 14 & $43 / 8$ & 108 & $30 / 7$ & \\
\hline & No & 1 & $3 / 1$ & 20 & $5 / 7$ & \\
\hline Use of disinfectonts & Especial liquid & 26 & $81 / 3$ & 254 & $72 / 2$ & 073 \\
\hline Use or cirsminectants & Especial solid & 2 & $6 / 3$ & 32 & $9 / 1$ & 0.13 \\
\hline & Others (not specific for hands) & 3 & $9 / 4$ & 46 & $13 / 1$ & \\
\hline Marital ctatur & Single & 9 & $28 / 1$ & 87 & $27 / 7$ & 067 \\
\hline Marital status & Married & 23 & $71 / 9$ & 265 & $75 / 3$ & $0.6 /$ \\
\hline & No record & 21 & $65 / 6$ & 294 & 83 & \\
\hline & Asthma & 0 & 0 & 2 & $0 / 6$ & \\
\hline & Diabetes & 0 & 0 & 3 & $9 / 0$ & \\
\hline & Hypertension & 1 & $3 / 1$ & 7 & 2 & \\
\hline History of chronic diseases & Heart diseases & 0 & 0 & 2 & $0 / 6$ & 0.13 \\
\hline & Thyroid disorders & 0 & 0 & 3 & $0 / 9$ & \\
\hline & Anemia & 2 & $6 / 3$ & 16 & $4 / 5$ & \\
\hline & Allergy & 6 & $18 / 8$ & 22 & $5 / 4$ & \\
\hline & Others & 2 & $6 / 3$ & 5 & $6 / 3$ & \\
\hline & No record & 30 & $93 / 8$ & 336 & $95 / 5$ & \\
\hline History of drug consumption & Yes & 2 & $6 / 3$ & 16 & $4 / 5$ & 0.00 \\
\hline$\rho, 1$. & No & 29 & $90 / 6$ & 315 & $89 / 5$ & $0 \Omega 0$ \\
\hline Smoking & Yes & 3 & $9 / 4$ & 37 & $10 / 5$ & 0.84 \\
\hline Hictory of f mily atone & Yes & 24 & 75 & 322 & $91 / 5$ & 000 \\
\hline History of family atopy & No & 8 & 25 & 30 & $8 / 5$ & 0.00 \\
\hline & Yes & 8 & 80 & 2 & 20 & \\
\hline History of atopy & No & 22 & $6 / 0$ & 343 & $94 / 0$ & 0.00 \\
\hline & $\mathrm{N} / \mathrm{A}$ & 2 & $22 / 2$ & 7 & $77 / 8$ & \\
\hline
\end{tabular}

dence rates of occupational dermatoses in Germany were 33.2\% and $23.9 \%$ among bakers and pastry cooks, respectively [23]. In a similar study conducted in Iran by Fathi et al., the incidence of occupational dermatitis among the food industry staff was $9.5 \%$ in a 5-year period in the city of Yazd [15]. In the present study, the one-year prevalence of dermatitis among food industry workers was $7.3 \%$. The following factors may account for the significant difference in the rate of occupational dermatitis between Iranians and other populations:

1- Genetic: Genetic effects, particularly atopic backgrounds, vary in different populations (7 and 8).

2- Risk factors for contact dermatitis: Food consumption patterns of Iran is different from other countries. For example, mustard which is a popular ingredient of salad dressings and induces contact dermatitis, is less commonly used in our country (7 and 8).

Furthermore, seafood types, meat types and spices are different from each other in East Asia, Europe and Iran. In addition, cooking traditions in some countries are different from our country.

3- Hand washing: Based on the guideline for the workplace and environmental health center, the workers of food supply, distribution and preservation units should frequently wash their hands with a particular method. Considering the significant role of soap and water in developing contact dermatitis, dermatitis types in different countries may be due to the number of hand-washing episodes per day. In this study, 77 participants $(20 \%)$ reported a 
Table 3. Comparing the Frequency of Jobs in Both Groups of Patients with Hand Eczema and Healthy Individuals.

\begin{tabular}{|c|c|c|c|c|c|c|c|c|c|c|c|}
\hline Job groups & hotel maid & Baker & $\begin{array}{c}\text { Seller of } \\
\text { vegeta- } \\
\text { bles }\end{array}$ & Cook & $\begin{array}{l}\text { Grocery } \\
\text { worker }\end{array}$ & Bucher & $\begin{array}{c}\text { Coffee } \\
\text { shop } \\
\text { worker }\end{array}$ & $\begin{array}{l}\text { Confec- } \\
\text { tioner }\end{array}$ & $\begin{array}{l}\text { Milk } \\
\text { seller }\end{array}$ & $\begin{array}{l}\text { Vege- } \\
\text { table } \\
\text { cleaner }\end{array}$ & Total \\
\hline Eczema & $\begin{array}{l}\text { NO. (Per- } \\
\text { centage) }\end{array}$ & $\begin{array}{c}\text { NO. (Per- } \\
\text { centage) }\end{array}$ & $\begin{array}{l}\text { NO. (Per- } \\
\text { centage) }\end{array}$ & $\begin{array}{l}\text { NO. (Per- } \\
\text { centage) }\end{array}$ & $\begin{array}{c}\text { NO. (Per- } \\
\text { centage) }\end{array}$ & $\begin{array}{l}\text { NO. (Per- } \\
\text { centage) }\end{array}$ & $\begin{array}{l}\text { NO. (Per- } \\
\text { centage) }\end{array}$ & $\begin{array}{l}\text { NO. (Per- } \\
\text { centage) }\end{array}$ & $\begin{array}{l}\text { NO. (Per- } \\
\text { centage) }\end{array}$ & $\begin{array}{l}\text { NO. (Per- } \\
\text { centage) }\end{array}$ & $\begin{array}{c}\text { NO. (Per- } \\
\text { centage) }\end{array}$ \\
\hline $\begin{array}{c}\text { Without hand } \\
\text { eczema }\end{array}$ & $10(8 / 2 \%)$ & $22(3 / 6 \%)$ & $28(8 \%)$ & $155(44 \%)$ & $33(4 / 9 \%)$ & $19(4 / 5 \%)$ & $17(8 / 4 \%)$ & $49(9 / 13 \%)$ & $14(4 \%)$ & $5(4 / 1 \%)$ & $352(100 \%)$ \\
\hline $\begin{array}{c}\text { With hand } \\
\text { eczema }\end{array}$ & $0(0 \%)$ & $2(3 / 6 \%)$ & $4(5 / 12 \%)$ & $18(3 / 56 \%)$ & $2(3 / 6 \%)$ & $0(0 \%)$ & $0(0 \%)$ & $6(8 / 18 \%)$ & $0(0 \%)$ & $0(0 \%)$ & $32(100 \%)$ \\
\hline Total & $10(6 / 2 \%)$ & $24(3 / 6 \%)$ & $32(8.3 \%)$ & $173(1 / 45 \%)$ & $35(1 / 9 \%)$ & $19(9 / 4 \%)$ & $17(4 / 4 \%)$ & $55(3 / 14 \%)$ & $14(6 / 3 \%)$ & $5(3 / 1 \%)$ & $384(100 \%)$ \\
\hline
\end{tabular}

Table 4. Evaluating the Quantitative Demographic and Job Variables in Two Groups of Patients with Hand Eczema and Healthy Individuals.

\begin{tabular}{|c|c|c|c|}
\hline Group & \multicolumn{2}{|c|}{ Average } & Test statistic (P-value) \\
\hline Variable & With hand eczema & Without hand eczema & T Test \\
\hline Age & $32 / 44 \pm 7 / 82$ & $32 / 68 \pm 9 / 64$ & $0 / 39$ \\
\hline No. of children under 4 & $0 / 49 \pm 0 / 37$ & $0 / 46 \pm 0 / 24$ & $0 / 32$ \\
\hline Duration of the first work experience & $7 / 06 \pm 7 / 01$ & $6 / 19 \pm 4 / 90$ & $0 / 31$ \\
\hline Work hours per week & $62 / 03 \pm 15 / 39$ & $66 / 45 \pm 17 / 70$ & $0 / 71$ \\
\hline Duration of the second work experience & 0 & $0 / 34 \pm 3 / 52$ & $0 / 80$ \\
\hline Duration of the last work experience & $2 / 27 \pm 1 / 15$ & $4 / 66 \pm 2 / 19$ & $0 / 85$ \\
\hline
\end{tabular}

Table 5. The Relationship between Annual Eczema Recurrence while Working and Occupation Types.

\begin{tabular}{|c|c|c|c|c|c|c|}
\hline Skin & \multicolumn{2}{|c|}{ Recurrence } & \multicolumn{2}{|c|}{ No recurrence } & \multirow{2}{*}{ Total } & \multirow{2}{*}{$\begin{array}{c}\text { Test } \\
\text { statistic }\end{array}$} \\
\hline job & No. & Percentage & No. & Percentage & & \\
\hline Baker & 1 & 50 & 1 & 50 & 2 & \multirow{6}{*}{$0 / 67$} \\
\hline Greengrocer & 1 & $33 / 3$ & 2 & $66 / 7$ & 3 & \\
\hline Cook & 13 & $72 / 2$ & 5 & $27 / 8$ & 18 & \\
\hline Grocery worker & 1 & 50 & 1 & 50 & 2 & \\
\hline Confectioner & 2 & 50 & 2 & 50 & 4 & \\
\hline Total & & 18 & & 11 & 29 & \\
\hline
\end{tabular}

Table 6. The Relationship between Eczema Improvement during weekends within a Year and Occupation Types.

\begin{tabular}{|c|c|c|c|c|c|c|}
\hline Condition & \multicolumn{2}{|c|}{ Not improved } & \multicolumn{2}{|c|}{ Improved } & \multirow{2}{*}{ Total } & \multirow{2}{*}{$\begin{array}{c}\text { Test } \\
\text { statistic }\end{array}$} \\
\hline job & No. & Percentage & No. & Percentage & & \\
\hline Baker & 1 & 50 & 1 & 50 & 2 & \multirow{6}{*}{$0 / 86$} \\
\hline Greengrocer & 1 & $33 / 3$ & 2 & $666 / 7$ & 3 & \\
\hline Cook & 9 & 50 & 9 & 50 & 18 & \\
\hline Grocery worker & 1 & 50 & 1 & 50 & 2 & \\
\hline Confectioner & 3 & 75 & 1 & 25 & 4 & \\
\hline Total & & 15 & & 14 & 29 & \\
\hline
\end{tabular}

low frequency of daily hand-washing. In addition, despite ensuring confidentiality, honesty of workers in completing questionnaires is still doubtful.

4- Unbalanced job distribution of the subjects: In the current study, different jobs related to raw foods, food preparation and preservation and food products were assessed. Similar studies were mostly concentrated on fast-food employees, bakers and confectioners. Hence, a reason for the presence of various prevalence rates may be the diversified variable in the subcategories of industry.

5- No defined job duty: Another distribution difference may be the duty of individuals in some units, so that there are no factors related to dermatitis. For example the exposure factors would change for a cook assistant working the whole day or all days of the week.

6- Climate conditions: The amount of moisture alters the frequency of dermatitis [2].

Current study demonstrated that a personal or family history of 
atopy and also gender differences affected the prevalence of the contact dermatitis, highlights the role of genetics in the outbreak of dermatitis in the study population. Similar studies showed a significant relationship between the hand washing frequency, job safety and etc., and the prevalence of contact dermatitis [22]. In this study, the aforementioned factors were different between dermatitis patients and healthy subjects. Nevertheless, no statistically significant difference was detected. The reasons to explain this issue may be explained as follows:

1- The presence of recall bias in symptom improvement during the holiday period. Considering the fact that symptom improvement requires at least one week off, the employees had probably no such long holidays since Mashhad is a touristic city.

2. The presence of reporting bias in hand washing frequency and using personal protective equipment, which is less frequent considering the random sampling.

3. Short-term employment record, economic status of the country and new employments may be among other influencing factors.

The number of children under 4 years was considered as a contributing factor to dermatitis but no statistically significant result was achieved in our study. This outcome could be explained as the lower percentage of females $(17.7 \%)$, who are more responsible for child care in our country (24). In this article, the average employment period in dermatitis group was more than the healthy group, however, the difference was not statistically significant. This may be due to a relatively low average of working years in the study population (7 years on average) according to the employment of young persons and frequent job change in industry. The findings of this study indicate that the annual prevalence of dermatitis is higher among men, which is probably because of the job type (women mostly work as packaging staff and men work as food preparers and have direct contact with raw materials). The incidence of chronic diseases was low in the study population (probably due to a lower average age) which made the application of statistical tests difficult. The level of education had no relationship with the prevalence of dermatitis, because of the proximity of the educational levels in the study groups. Moreover, the reporting bias (inaccurate reporting of educational level) was inevitable.

\section{Advantages}

The translation and assessment of reliability and validity of Nordic skin Questionnaire was a major advantage of this study. The study sample is relatively larger than similar studies.

\section{Disadvantages}

It was not possible to assure the job relatedness of a skin disease due to the unavailability of a certain paraclinical test for food materials and high costs of testing procedures.

\section{Suggestions}

1- Developing electronic records related to the information of personnel is one of the main infrastructure actions. Considering the reasonable initial costs of launching this system as well as training people, the industrial system and related occupational diseases could be assessed more accurately. Finally, this could lessen the financial burden of insurance and corporations and also reduces the inconvenience of employees in the upcoming years. 2- Detecting patients with atopy during periodical job examinations helps to regularly track any probable skin disorder in future.

\section{References}

[1]. Williams N. AMA guides to the evaluation of work ability and return to work.

[2]. Rosenstock L, Cullen M, Brodkin C, Redlich C. Textbook of clinical occupational and environmental medicine.

[3]. LaDou J, Harrison R. Current occupational \& environmental medicine. 2014.

[4]. Rom WN, Markowitz S. Environmental and Occupational Medicine. Philadelphia: Wolters Kluwer Health. 2011.

[5]. Occupational dermatitis in the catering and food industries. [http://www. hse.gov.uk/food/dermatitis.htm] [Nov 29, 2012] .

[6]. DermNet New Zealand: All about the skin. [http://www.dermnetnz.org/ topics/occupational-skin-diease] [2012].

[7]. Muraro A, Werfel T, Hoffmann-Sommergruber K, Roberts G, Beyer K, Bindslev-Jensen C, et al. EAACI food allergy and anaphylaxis guidelines: diagnosis and management of food allergy. Allergy. 2014 Aug;69(8):1008-25.

[8]. Wang J, Sampson HA. Food allergy. J. Clin. Investig. 2011 Mar 1;121(3):827-35.

[9]. Diepgen TL, Coenraads PJ. The epidemiology of occupational contact dermatitis. Int Arch Occup Environ Health. 1999 Nov;72(8):496-506.

[10]. Droste J, Vermeire P, Van Sprundel M, Bulat P, Braeckman L, Myny K, et al. Occupational exposure among bakery workers: impact on the occurrence of work-related symptoms as compared with allergic characteristics. J Occup Environ Med. 2005 May;47(5):458-65.Pubmed PMID: 15891524.

[11]. Diepgen TL, Scheidt R, Weisshaar E, John SM, Hieke K. Cost of illness from occupational hand eczema in Germany. Contact Derm. 2013 Aug;69(2):99-106.

[12]. Goldsmith L, Katz S, Gilchrest BA, Paller AS, Leffell DJ, Wolff K. Fitzpatrick's Dermatology in General Medicine, Ed. McGrawHill Medical. 2012:2421-9.

[13]. Griffiths C, Barker J, Bleiker TO, Chalmers R, Creamer D, editors. Rook's textbook of dermatology. John Wiley \& Sons; 2016 Feb 29.

[14]. Behroozy A, Keegel TG. Wet-work exposure: a main risk factor for occupational hand dermatitis. Saf Health Work. 2014 Dec 1;5(4):175-80.

[15]. Fathi F, Jafarpoor M. Matching evaluation between occupational contact dermatitis and various jobs in Yazd in during 2007-2012. Acta Med Iran. 2013;51(11):793-8.Pubmed PMID: 24390950.

[16]. Steiner MF, Dick FD, Scaife AR, Semple S, Paudyal P, Ayres JG. High prevalence of skin symptoms among bakery workers. Occup Med. 2011 Jun 1;61(4):280-2.

[17]. Bauer A, Geier J, Elsner P. Type IV allergy in the food processing industry: sensitization profiles in bakers, cooks and butchers. Contact Derm. 2002 Apr;46(4):228-35.Pubmed PMID: 12081702.

[18]. Kurpiewska J, Liwkowicz J, Benczek K, Padlewska K. A survey of workrelated skin diseases in different occupations in Poland. Int J Occup Saf Ergon. 2011 Jan 1;17(2):207-14.

[19]. Peltonen L, Wickström G, Vaahtoranta M. Occupational dermatoses in the food industry. Dermatosen in Beruf und Umwelt Occupation and environment. 1984;33(5):166-9.

[20]. Bauer A, Kelterer D, Stadeler M, Schneider W, Kleesz P, Wollina U, et al. The prevention of occupational hand dermatitis in bakers, confectioners and employees in the catering trades. Preliminary results of a skin prevention program. Contact Dermatitis. 2001 Feb;44(2):85-8.Pubmed PMID: 11205409 .

[21]. Smith TA. Occupational skin conditions in the food industry. Occup. Med. 2000 Nov 1;50(8):597-8.

[22]. Teo S, Teik-Jin Goon A, Siang LH, Lin GS, Koh D. Occupational dermatoses in restaurant, catering and fast-food outlets in Singapore. Occup Med (Lond). 2009 Oct;59(7):466-71.Pubmed PMID: 19297338.

[23]. Mahler V. Occupational Contact Dermatitis: Chefs and Food Handlers. In: Johansen JD, Frosch PJ, Lepoittevin J-P, editors. Contact Dermatitis. Berlin, Heidelberg: Springer Berlin Heidelberg; 2011. p. 853-64.

[24]. Abbasi-Shavazi MJ, Inhorn MC, Razeghi-Nasrabad HB, Toloo G. The "Iranian ART Revolution" infertility, assisted reproductive technology, and third-party donation in the Islamic Republic of Iran. J. Middle East Women's Stud. 2008;4(2):1-28. 